\title{
Penerapan Pendekatan Saintifik dengan Media Video dalam Peningkatan Pembelajaran IPS Tentang Kegiatan Ekonomi pada Siswa Kelas IV SD Negeri 2 Tanggeran Tahun Ajaran 2017/2018
}

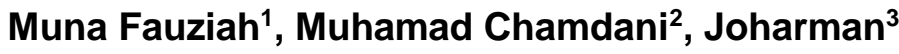 \\ 1,2,3 Universitas Sebelas Maret \\ munafauziah6@gmail.com
}

\section{Article History}

accepted 01/02/2019

approved 01/03/2019

published 01/04/2019

\begin{abstract}
The objective of this research isto improve social science learning about economic activity through the implementation of scientific approach using video. This research is a collaborative Classroom Action Research (CAR) conducted within three cycles. Subjects of the research were 21 students of the fourth grade of SD Negeri 2 Tanggeran. Validity of data in this research was analyzed using triangulation of technique and triangulation of sources. The results of this research show that the implementation of scientific approach using video can improve social science learning about economic activity for the fourth grade students of SD Negeri 2 Tanggeran. It was proven by the increase of learning process percentage of social science in the first cycle $66.58 \%$, in the second cycle $77.97 \%$, and in the third cycle $90.48 \%$. In addition, the increase of learning outcomes percentage of social science in the first cycle $69.21 \%$, in the second cycle $77.97 \%$, and in the third cycle $85.71 \%$. The conclusion of this research is the implementation of scientific approach using video can improve social science learning about economic activity for the fourth grade students of SD Negeri 2 Tanggeran in the academic year of 2017/2018.
\end{abstract}

Keywords: scientific approach, video media, social science learning

\begin{abstract}
Abstrak
Penelitian ini bertujuan untuk meningkatkan pembelajaran IPS dengan menerapkan pendekatan saintifik dengan media video. Penelitian ini merupakan penelitian tindakan kelas kolaboratif yang dilaksanakan selama tiga siklus. Subjek penelitian ini adalah siswa kelas IV SD Negeri 2 Tanggeran berjumlah 21 siswa. Uji validitas data menggunakan triangulasi teknik dan triangulasi sumber. Hasil penelitian ini menunjukkan bahwa penerapan pendekatan saintifik dengan media video dapat meningkatkan pembelajaran IPS tentang kegiatan ekonomi pada siswa kelas IV SD Negeri 2 Tanggeran. Hal ini dapat dibuktikan dengan persentase ketuntasan proses belajar IPS pada siklus I sebesar $66,58 \%$, siklus II $77,97 \%$, dan siklus III 90,48\%. Lalu, ketuntasan hasil belajar IPS pada siklus I sebesar $69,21 \%$, siklus II $77,97 \%$, dan siklus III $85,71 \%$. Simpulan dalam penelitian ini adalah penerapan pendekatan saintifik dengan media video dapat meningkatkan pembelajaran IPS tentang kegiatan ekonomi pada siswa kelas IV SD Negeri 2 Tanggeran tahun ajaran 2017/2018.
\end{abstract}

Kata kunci: Pendekatan saintifik, Media Video, Pembelajaran IPS 


\section{PENDAHULUAN}

Pendidikan merupakan salah satu langkah pemerintah untuk mengembangkan kualitas sumber daya manusia yang sesuai dengan tujuan pendidikan nasional yakni mengembangkan potensi siswa agar menjadi manusia yang beriman, bertakwa, berakhlak mulia, berkarakter, demokratis, dan bertanggung jawab (Depdiknas, 2011: 8).

Upaya yang dapat dilakukan untuk mencapai tujuan tersebut ialah kerja sama yang baik, antara guru dengan siswa. Guru harus memilih pendekatan dan media yang tepat yang disesuaikan dengan karakteristik siswa dan materi yang akan dipelajari agar terdapat hubungan antara pendekatan, media, dan materi pembelajaran.

Pendidikan IPS di sekolah dasar menurut Susanto (2014: 10) adalah bidang studi yang menganalisis gejala sosial di masyarakat dengan meninjau berbagai aspek kehidupan. Sapriya (2014: 12) menjelaskan bahwa tujuan IPS di sekolah dasar adalah untuk mempersiapkan siswa agar berpengetahuan, terampil, dan ikut serta kegiatan di masyarakat. Pembelajaran IPS di sekolah dasar hendaknya sesuai dengan karakteristik siswa sekolah dasar yang senang melakukan percobaan dan didukung oleh rasa ingin tahu yang besar.

Berdasarkan uraian di atas, maka dapat disimpulkan bahwa pembelajaran IPS siswa kelas IV sekolah dasar adalah serangkaian kegiatan pembelajaran yang mengkaji masalah dan gejala sosial di masyarakat dan terintegrasi dari berbagai cabang ilmu sosial untuk mencapai tujuan pembelajaran, meliputi proses dan hasil belajar yang disesuaikan dengan karakteristik siswa sekolah dasar.

Realita yang terjadi di lapangan menunjukkan pembelajaran IPS masih dilakukan dengan model konvensional. Hasil wawancara yang dilakukan peneliti dengan guru kelas IV di SD Negeri 2 Tanggeran menunjukkan bahwa nilai IPS masih termasuk rendah, karena dari 21 siswa di kelas IV, terdapat 11 siswa yang mendapatkan nilai di bawah KKM (67) atau sekitar 52, 38\%. Adapun penyebab rendahnya hasil belajar tersebut yaitu: (1) guru masih menggunakan metode ceramah; (2) pembelajaran didominasi oleh guru; (3) hanya beberapa siswa yang aktif menjawab pertanyaan guru dan menyampaikan pendapat; (4) media yang digunakan kurang inovatif, sehingga hasil belajar IPS yang kurang maksimal.

Inovasi pembelajaran sangat diperlukan untuk mengatasi masalah tersebut. Salah satu inovasi yang dapat dilakukan ialah dengan memadukan pendekatan dengan media yang sesuai dengan karakteristik siswa sekolah dasar. Solusi yang dianggap tepat untuk mengatasi permasalahan tersebut ialah dengan menerapkan pendekatan saintifik dengan media video.

Daryanto (2014: 51) menjelaskan bahwa pendekatan saintifik adalah proses pembelajaran dengan rancangan yang sistematis agar siswa aktif menemukan dan mengembangkan konsep ilmiah melalui tahapan mengamati, mengajukan hipotesis, mengumpulkan dan menganalisis data, menyimpulkan, serta mengkomunikasikan hasil. Langkah-langkah pendekatan saintifik menurut Dyer (Sani, 2017: 53) yaitu: (a) mengamati; (b) menanya; (c) mencoba/mengumpulkan informasi; (d) menalar/ asosiasi; (e) membentuk jejaring/ melakukan komunikasi.

Langkah pendekatan saintifik akan efektif jika dipadukan dengan media video. Daryanto (2013: 87) menjelaskan bahwa media video adalah bahan ajar non cetak yang menyajikan gambar bergerak disertai suara dan dapat secara langsung sampai kehadapan siswa. Sementara itu, Asyhar (2011: 74) mengatakan, "media video merupakan rekaman gambar dan suara dalam kaset pita video ke dalam pita magnetik".

Dari uraian di atas, dapat disimpulkan bahwa pendekatan saintifik dengan media video adalah pendekatan pembelajaran yang dirancang secara sistematis agar melibatkan siswa dalam aktivitas pembelajaran untuk memperoleh data melalui kegiatan mengamati, menanya, mengumpulkan informasi, menalar, dan 
mengkomunikasikan yang disajikan dalam bentuk video pembelajaran mengenai materi yang akan dipelajari. Langkah-langkah penerapan pendekatan saintifik dengan media video adalah sebagai berikut: (1) mengamati video, (2) menanya berdasarkan video, (3) mengumpulkan informasi berdasarkan video, (4) menalar, dan (5) mengkomunikasikan.

Rumusan masalah pada penelitian ini yaitu apakah penerapan pendekatan saintifik dengan media video dapat meningkatkan pembelajaran IPS tentang kegiatan ekonomi pada siswa kelas IV SD Negeri 2 Tanggeran tahun ajaran 2017/2018?.

Tujuan penelitian ini yaitu untuk meningkatkan pembelajaran IPS tentang kegiatan ekonomi dengan menerapkan pendekatan saintifik dengan media video pada siswa kelas IV SD Negeri 2 Tanggeran tahun ajaran 2017/2018.

\section{METODE}

Penelitian ini dilaksanakan di SD Negeri 2 Tanggeran yang dimulai dari bulan Oktober sampai Maret 2018. Subjek penelitian ini yaitu siswa kelas IV berjumlah 21 siswa yang terdiri dari 12 siswa laki-laki dan 9 siswa perempuan.

Data pada penelitian ini terbagi menjadi dua yaitu data kualitatif dan data kuantitatif. Data kuantitatif berupa hasil observasi, hasil penilaian proses, dan hasil belajar siswa pada mata pelajaran IPS tentang kegiatan ekonomi, sedangkan data kualitatif berupa hasil wawancara mengenai pelaksanaan pembelajaran IPS menggunakan pendekatan saintifik dengan media video. Adapun teknik pengumpulan data yang digunakan yaitu tes, observasi, dan wawancara.

Teknik uji validitas data pada penelitian ini menggunakan teknik triangulasi, yaitu triangulasi teknik dan sumber. Teknik analisis data yang digunakan diambil dari Miles dan Huberman yaitu reduksi data, penyajian data, dan penarikan kesimpulan (Sugiyono, 2016: 337-345).

Indikator kinerja penelitian dalam penelitian ini yaitu $80 \%$. Prosedur penelitian ini menggunakan model Kemmis dan MC. Taggart (Arikunto, 2014: 137) yang terdiri dari empat tahapan, yaitu: (1) perencanaan, (2) pelaksanaan, (3) pengamatan, (4) refleksi.

\section{HASIL DAN PEMBAHASAN}

Penerapan pendekatan saintifik dengan media video dalam peningkatan pembelajaran IPS meliputi dua aspek yaitu proses dan hasil belajar siswa yang dilakukan selama tiga siklus. Penerapan pendekatan saintifik dengan media video dalam peningkatan pembelajaran IPS dinyatakan berhasil. Hal ini dibuktikan dengan adanya peningkatan pada aspek penilaian proses dan hasil belajar siswa yang telah mencapai indikator penelitian yaitu $80 \%$.

Aspek penilaian proses belajar siswa mengalami peningkatan dengan perbandingan sebagai berikut.

Tabel 1. Perbandingan Penilaian Proses Tiap Siklus

\begin{tabular}{cccc}
\hline \multirow{2}{*}{$\begin{array}{c}\text { Siklu } \\
\text { S }\end{array}$} & $\begin{array}{c}\text { Rata- } \\
\text { rata }\end{array}$ & \begin{tabular}{c} 
Tuntas \\
\cline { 3 - 4 } Persentase (\%)
\end{tabular} & $\begin{array}{c}\text { Belum } \\
\text { Tuntas }\end{array}$ \\
\hline I & 75,13 & 66,58 & 33,42 \\
\hline II & 80,05 & 77,97 & 22,03 \\
\hline III & 83,57 & 90,48 & 9,52 \\
\hline
\end{tabular}

Berdasarkan tabel 1, dapat disimpulkan bahwa penilaian proses belajar siswa dengan aspek tanggung jawab, kerja sama, dan percaya diri mengalami peningkatan 
pada setiap siklusnya. Persentase ketuntasan pada siklus I mencapai $66,58 \%$, siklus II mencapai 77,97\%, siklus III mencapai 90,48\%. Data tersebut menunjukkan bahwa proses belajar siswa telah mencapai indikator kinerja penelitian sebesar $80 \%$.

Peningkatan persentase penilaian proses dari siklus I sampai III sejalan dengan penelitian Zhong (2014: 1507-1508) yang menemukan bahwa pendekatan saintifik dapat menarik perhatian siswa dan melatih kemampuan belajar mandiri. Penerapan video dalam pembelajaran akan membuat pembelajaran lebih menarik dan mengesankan (Akram, Sufiana, dan Malik, 2012: 10597).

Aspek hasil belajar siswa juga mengalami peningkatan dengan perbandingan sebagai berikut.

Tabel 2. Perbandingan Hasil Belajar Siswa Tiap Siklus

\begin{tabular}{cccc}
\hline \multirow{2}{*}{$\begin{array}{c}\text { Siklu } \\
\text { S }\end{array}$} & $\begin{array}{c}\text { Rata- } \\
\text { rata }\end{array}$ & Tuntas & $\begin{array}{c}\text { Pelum } \\
\text { Tuntas }\end{array}$ \\
\hline I & 76,09 & 69,21 & 30,79 \\
\hline II & 76,40 & 77,97 & 22,03 \\
\hline III & 80 & 85,71 & 14,29 \\
\hline
\end{tabular}

Berdasarkan tabel 2, maka disimpulkan bahwa hasil belajar siswa pada tiap siklus selalu meningkat. Persentase siswa tuntas pada siklus I mencapai 69,21\%, siklus II mencapai $77,97 \%$, siklus III mencapai $85,71 \%$. Data tersebut menunjukkan bahwa hasil belajar siswa telah mencapai indikator kinerja penelitian sebesar $80 \%$.

Penerapan pendekatan saintifik memberikan pengaruh positif terhadap pembelajaran IPS. Hasil penelitian ini diperkuat dengan penelitian yang dilakukan oleh Putri, Suhartono, dan Suripto (2016: 728) yang membuktikan bahwa pendekatan saintifik dengan media video dapat meningkatkan keterampilan menulis puisi.

\section{SIMPULAN}

Berdasarkan hasil penelitian dan pembahasan, maka dapat disimpulkan bahwa penerapan pendekatan saintifik dengan media video terbukti dapat meningkatkan pembelajaran IPS tentang kegiatan ekonomi pada siswa kelas IV SD Negeri 2 Tanggeran tahun ajaran 2017/2018.

Berkaitan dengan hasil tersebut, maka peneliti memberikan saran sebagai berikut: (1) siswa harus aktif mengikuti pembelajaran, (2) guru lebih kreatif dan inovatif dalam pembelajaran, (3) sekolah sebaiknya memberikan sarana yang lengkap untuk menunjang pembelajaran, (4) peneliti lain dapat menerapkan pendekatan saintifik dengan media video pada materi IPS yang lain atau pada mata pelajaran lain.

\section{DAFTAR PUSTAKA}

Akram, S., Sufiana, \& Malik, K. (2012). Use of audio visual aids for effective teaching of biology at secondary schools level. Elixir International Journal, 50 (4): 1059710605.

Arikunto. (2014). Prosedur Penelitian Suatu Pendekatan Praktik. Jakarta: Rineka Cipta. Asyhar, R. (2011). Kreatif Pengembangan Media Pembelajaran. Jakarta: Gaung Persada Press.

Daryanto. (2013). Media Pembelajaran. Yogyakarta: Gava Media.

Daryanto. (2014). Pendekatan Pembelajaran Saintifik. Kurikulum 2013. Yogyakarta: Gava Media. 
Putri, A.A., Suhartono, \& Susiani, T.S. (2016). Pendekatan Saintifik dengan Media Video dalam Peningkatan Keterampilan Menulis Puisi pada Siswa Kelas V SD Negeri Kembaran Tahun Ajaran 2015/2016. Kalam Cendekia, 4 (6.1): 724-729.

Sapriya. (2014). Pendidikan IPS Konsep dan Pembelajaran. Bandung: PT Remaja Rosdakarya.

Sani, R.A. (2017). Pembelajaran Saintifik Untuk Implementasi Kurikulum 2013. Jakarta: Bumi Aksara.

Sugiyono. (2016). Metode Penelitian Pendidikan (Pendekatan Kuantitatif, Kualitatif, dan $R \& D$ ). Bandung: ALFABETA CV.

Susanto, A. (2014). Pengembangan Pembelajaran IPS di Sekolah Dasar. Jakarta: Prenadamedia Group.

Depdiknas. (2011). Undang-Undang Sistem Pendidikan Nasional. Yogyakarta: Pustaka Pelajar.

Zhong, G.Q. (2014). Training of scientific thinking methods in teaching of inorganic and analytical chemistry. Journal of Chemical and Pharmaceutical Research, 6 (7): 1503-1508.

Nur, Kamaludin, dan Djirimu. (2014). Penggunaan Metode Inkuiri Terbimbing untuk Meningkatkan Hasil Belajar Siswa pada Pokok Bahasan Tumbuhan Hijau di Kelas V SDN 2 Bora. Jurnal Kreatif Tadulako Online, 5(6): 126-133.

Sanjaya, W. (2013). Strategi Pembelajaran: Implementasi Standar Proses Pendidikan. Jakarta: Kencana Pramedia Group.

Sugiyono. (2011). Metode Penelitian Kuantitatif, Kualitatif, dan R\&D. Bandung: Alfabeta.

Sulistyorini, S. \& Supartono. (2007). Model Pembelajaran IPA Sekolah Dasar dan Penerapannya dalam KTSP. Yogyakarta: Tiara Wacana.

Yamin, M. (2010). Kiat Membelajarkan Siswa. Jakarta: Gaung Persada Press. 